\title{
PENGARUH MODEL DISCOVERY LEARNING BERBANTU SOFTWARE WINGEOM TERHADAP KEMAMPUAN PEMAHAMAN KONSEP MATEMATIS PESERTA DIDIK
}

\author{
Samuel Setyo Nugroho Putro ${ }^{1}$, M. Soenarto ${ }^{2}$, Ayu Faradillah ${ }^{3}$ \\ Universitas Muhammadiyah Prof. DR. HAMKA, Jl. Tanah Merdeka, Jakarta Timur \\ ${ }^{1}$ samuelputra11@gmail.com
}

\begin{abstract}
Abstrak
Penelitian bertujuan untuk mengetahui pengaruh model discovery learning berbantu software wingeom terhadap kemampuan pemahaman konsep matematis peserta didik. Metode penelitian yang digunakan adalah Quasi-Experimental dengan Intact-Group Comparison design. Populasi penelitian mencakup seluruh peserta didik kelas VIII. Penelitian ini dilaksanakan di SMP Desa Putera Jakarta pada kelas VIII semester genap pada tahun pelajaran 2017/2018. Teknik pengambilan sampel menggunakan metode sampling purposive diperoleh 80 peserta didik terdiri dari 40 peserta didik untuk kelas eksperimen dan 40 peserta didik untuk kelas kontrol. Instrumen yang digunakan berupa tes uraian yang terdiri dari 8 soal kemudian diuji validitas dan reliabilitas. Data hasil penelitian telah diuji normalitas, homogenitas didapat data yang berdistribusi normal dan kedua kelompok homogen. Pengujian hipotesis dilakukan menggunakan uji- $t$ dihasilkan sebesar 6,345 dengan effect size sebesar 1,426 termasuk dalam kriteria tinggi. Hasil penelitian menyimpulkan rata-rata kelas eksperimen lebih besar daripada kelas kontrol, sehingga terdapat pengaruh model discovery learning berbantu software wingeom terhadap kemampuan pemahaman konsep matematis peserta didik.
\end{abstract}

Kata Kunci: Model Discovery Learning, Software Wingeom, Kemampuan Pemahaman Konsep Matematis Peserta Didik

\begin{abstract}
The aim of this research to know the influence of discovery learning wingeom assisted software to mathematics concepts understanding ability to learners'. The research method was used Quasi-Experimental with design type of Intact-Group Comparison design. The research of population took in all learners' of grade VIII. This research was held at SMP Desa Putera Jakarta grade VIII second semester of academic year 2017/2018. This research was used sampling purposive method to obtained sample that representative and it got 80 learner that 40 learner for experiment class and 40 learner for control class. The instrument was used the structure items consist of 8 items result test validity and reliability. The data of research tested normality, homogeneity it got the data of normal distribution and both is homogeneous class. The submitted hypothesis use test-t resulted 6,345 and it had size effect 1,426 in high criterion. In conclusion of this research the mean of experiment class higher than the mean of control class, so that there is the influence of discovery learning wingeom assisted software to mathematics concepts understanding ability to learners'.
\end{abstract}

Keywords: Discovery Learning Model, Software Wingeom, Mathematics Concepts Understanding Ability to Learners'

\section{Pendahuluan}

Matematika merupakan suatu mata pelajaran yang diajarkan pada setiap jenjang pendidikan di Indonesia mulai dari Sekolah Dasar (SD) sampai Perguruan Tinggi (PT). Dengan kurikulum 2013 yang digunakan oleh Indonesia saat ini, peserta didik dituntut untuk aktif 
mencari, mengolah, mengkonstruksi, dan menggunakan pengetahuannya. Menurut Priyo (Tianingrum \& Sopiany, 2017: 440) "pemahaman yang tidak mantap akan mengakibatkan peserta didik mengalami kesulitan dalam penyampaian soal-soal, serta penyebab rendahnya pemahaman peserta didik terhadap matematika berakar pada peserta didik yang cenderung menghafal konsep daripada proses penguasaan konsep”. Salah satu cara untuk permasalahan mengenai kurangnya minat peserta didik dengan pelajaran matematika yaitu dengan kemampuan pemahaman konsep pada peserta didik.

Kemampuan pemahaman konsep merupakan suatu aspek yang sangat penting dalam pembelajaran, karena dengan memahami konsep peserta didik dapat mengembangkan kemampuannya dalam setiap materi pelajaran. Kemampuan pemahaman konsep merupakan suatu kapasitas peserta didik dalam memahami konsep yang berhubungan dengan matematika. Karena konsep matematika yang satu dengan yang lain berkaitan sehingga untuk mempelajarinya harus berkesinambungan. Jika peserta didik telah memahami konsep-konsep, maka akan memudahkan peserta didik untuk mempelajari konsep-konsep matematika berikutnya yang lebih kompleks. Dalam kegiatan pembelajaran, hal yang paling penting adalah pencapaian atau tujuan kemampuan peserta didik dalam memahami berdasarkan pengalaman proses belajarnya. Memahami sebuah konsep dalam suatu pembelajaran lebih penting dibanding dengan menghafal. Namun menanamkan pemahaman konsep kepada pesesrta didik merupakan hal yang tidak mudah, karena setiap peserta didik memiliki kemampuan yang bervariasi dalam memahami sebuah konsep. Tetapi pemahaman sebuah konsep matematika harus diupayakan secara optimal untuk keberhasilan peserta didik itu sendiri. Pemahaman konsep matematis adalah mengerti benar tentang konsep matematika, yaitu peserta didik dapat menerjemahkan, menafsirkan, dan menyimpulkan suatu konsep berdasarkan pembentukan pengetahuannya.

Supaya konsep-konsep dan teorema-teorema dapat diaplikasikan ke situasi yang lain, perlu adanya keterampilan menggunakan konsep-konsep dan teorema-teorema tersebut. Oleh karena itu, pembelajaran matematika harus ditekankan ke arah pemahaman konsep. Suatu konsep yang dikuasai peserta didik semakin baik apabila disertai dengan pengaplikasian. Peserta didik dikatakan telah memahami konsep apabila ia telah mampu mengabstraksikan sifat yang sama, yang merupakan ciri khas dari konsep yang dipelajari, dan telah mampu membuat generalisasi terhadap konsep tersebut. Dapat dipahami bahwa kemampuan pemahaman konsep matematis menginginkan peserta didik mampu memanfaatkan atau mengaplikasikan apa yang telah dipahaminya ke dalam kegiatan belajar. Jika peserta didik telah memiliki pemahaman yang baik, maka peserta didik tersebut siap memberi jawaban yang pasti atas pernyataan-pernyataan atau masalah-masalah dalam belajar. Indikator yang terdapat dalam kemampuan pemahaman 
konsep yang termuat dalam Peraturan Dirjen Dikdasmen Nomor 506/C/Kep/PP/2004 (Zulkarnain, 2014) yaitu. (1) menyatakan sebuah konsep; (2) mengklasifikasi objek-objek menurut sifat-sifat tertentu; (3) menyajikan konsep dalam bentuk representrasi matematis; dan (4) mengaplikasikan konsep atau algoritma pemecahan masalah. Sehingga kemampuan pemahaman konsep matematis pada penelitian ini adalah peserta didik mampu memahami konsep-konsep yang ada dalam matematika.

Guru perlu mempersiapkan dan mengatur strategi penyampaian materi matematika kepada peserta didik. Strategi tersebut dapat berupa memilih bahan ajar yang dipadukan dengan model pembelajaran yang tepat dimana peserta didik dilibatkan secara aktif dalam proses pembelajaran sehingga dapat membuat kemampuan pemahaman konsep pada peserta didik dan tercapainya hasil belajar peserta didik yang diharapkan. Peran guru dalam kegiatan belajar mengajar adalah sebagai fasilitator dan motivator untuk mengoptimalkan belajar peserta didik. Guru seharusnya tidak memberi pengetahuan jadi, tetapi hendaknya secara aktif membangun pengetahuan dalam pikiran mereka sendiri. Oleh karena itu diperlukan pendekatan pembelajaran yang dapat mengaktifkan peserta didik dalam kegiatan belajar mengajar.

Dalam proses pembelajaran, penerapan strategi pembelajaran kurang bervariasi, sehingga kurangnya kemampuan pemahaman konsep matematik peserta didik. Model pembelajaran yang dipilih haruslah model pembelajaran yang mampu membuat aktif peran peserta didik dalam proses pembelajaran. Menurut Bruner (2009) menyatakan bahwa pembelajaran terjadi melalui proses penemuan yang memprioritaskan pemikiran, percobaan, dan penyelidikan. Orang-orang yang menggunakan penemuannya sendiri dalam pembelajaran, akan lebih menambah kepercayaan diri. Burner (2014) memberikan empat alasan untuk menggunakan model discovery learning, sebagai berikut: (1) untuk membuat impuls pemikiran; (2) untuk mengembangkan motivasi dalam diri pada motivasi luar; (3) untuk mempelajari cara penemuan; dan (4) mengembangkan pemikiran. Sehingga, dengan menerapkan model discovery learning pemikiran peserta didik akan berkembang karena peserta didik dituntut untuk aktif dan bebas untuk mengeksplorasi pendapatnya.

Menurut Sani (2014) discovery adalah menemukan konsep melalui serangkaian data atau informasi yang diperoleh melalui pengamatan atau percobaan. Data yang diperoleh menjadi salah satu acuan bagi peserta didik untuk memperoleh suatu konsep yang ingin ditemukan. Guru dalam pembelajaran model ini ikut berperan sebagai mediator peserta didik dalam proses mencari informasi. Guru dapat memberikan beberapa informasi yang nantinya dapat dikembangkan oleh peserta didik, sehingga sebuah konsep dapat ditemukan oleh peserta didik. Melalui belajar penemuan, peserta didik juga dapat belajar berpikir analisis dan mencoba 
memecahkan sendiri masalah yang dihadapi. Selain itu konsep yang dapat ditemukan sendiri akan bertahan lama dalam ingatan peserta didik sebagai penemu konsep tersebut. Model discovery learning merupakan pembelajaran yang menekankan pada pengalaman langsung dan pentingnya pemahaman struktur atau ide-ide penting terhadap suatu disiplin ilmu, melalui keterlibatan peserta didik secara aktif dalam pembelajaran. Bahan ajar yang disajikan dalam bentuk pertanyaan atau permasalahan yang harus diselesaikan. Jadi peserta didik memperoleh pengetahuan yang belum diketahuinya tidak melalui pemberitahuan, melainkan melalui penemuan sendiri. Penggunaan discovery learning, ingin merubah kondisi belajar yang pasif menjadi aktif dan kreatif. Mengubah pembelajaran yang awalnya peserta didik hanya menerima informasi keseluruhan dari guru, dan sekarang mencari sendiri sebuah informasi tersebut melalui konsep. Dengan kelebihan dari model discovery learning yaitu memungkinkan peserta didik berkembang dengan cepat, membantu peserta didik memperkuat konsep dirinya, dan peserta didik akan mengerti konsep dasar, sehingga model discovery learning baik digunakan untuk kemampuan pemahaman konsep. Langkah-langkah model discovery learning yaitu. (1) guru menjelaskan tujuan pembelajaran; (2) guru membagi petunjuk praktikum/eksperimen; (3) peserta didik melaksanakan eksperimen di bawah pengawasan guru; (4) guru menunjukkan gejala yang diamati; dan (5) peserta didik menyimpulkan hasil eksperimen. Melalui tahap-tahap ini peserta didik dapat menemukan sendiri hasil dari penemuan konsep yang mereka cari dari beberapa percobaan dan pengumpulan informasi.

Selain penggunaan model pembelajaran, keberadaan media juga dapat berpengaruh terhadap kemampuan pemahaman konsep matematika. Menurut Sutirman (2013) media merupakan komponen sumber belajar atau wahana fisik yang mengandung materi instruksional di lingkungan siswa yang dapat merangsang siswa untuk belajar. Dalam hal ini media yang akan digunakan yaitu software matematika bernama wingeom. Program wingeom merupakan salah satu perangkat lunak komputer matematika dinamik (dynamic mathematic software) untuk topik geometri. Program ini memuat program wingeom 2-dim untuk geometri dimensi dua dan wingeom 3-dim untuk geometri dimensi tiga dalam jendela yang terpisah. Software wingeom dipilih menjadi media yang digunakan karena software ini merupakan salah satu software yang digunakan untuk materi geometri ruang. Dalam segi tampilan dan juga cara penggunaan software ini mudah untuk digunakan dan dimengerti, sehingga dapat membantu dalam memberikan informasi kepada peserta didik untuk merangsang dan menemukan sebuah konsep dari bangun ruang materi yang diajarkan.

Model discovery learning berbantu media software wingeom dapat memaksimalkan potensi peserta didik, khususnya pada kemampuan pemahaman konsep matematis. Sehingga 
terdapat pengaruh model discovery learning berbantu software wingeom terhadap kemampuan pemahaman konsep matematis peserta didik.

\section{Metode Penelitian}

Penelitian ini menggunakan metode quasi experimen, karena tidak mengacak subyek dan membentuk kelas baru, melainkan subyek yang ada dalam kelas tersebut. Desain penelitian yang digunakan adalah Intact-Group Comparison Design. Pada penelitian ini, peneliti melakukan perlakuan terhadap kelompok eksperimen untuk mengetahui kemampuan pemahaman konsep matematis peserta didik dan membandingkan dengan kelompok kontrol yang tidak mendapat perlakuan. Setelah diberikan metode pembelajaran yang berbeda, kedua kelompok kelas diberikan tes dengan soal yang sama. Kemudian dibandingkan kemampuan pemahaman konsep matematis peserta didik dari kedua kelompok kelas tersebut.

Setelah memberikan perlakuan yang berbeda pada kedua kelompok, yaitu kelompok eksperimen diajarkan dengan menggunakan model discovery learning berbantu software wingeom, maka diberikan tes akhir dengan soal yang sama kemudian hasil tes kedua kelompok tersebut dianalisis. Dengan demikian dari tes dapat dibuktikan apakah kemampuan pemahaman konsep matematis kelompok eksperimen lebih tinggi dari kemampuan pemahaman konsep matematis kelompok kontrol.

\section{Hasil dan Pembahasan}

Penelitian dilaksanakan di SMP Desa Putera pada tanggal 19 April hingga 14 Mei 2018. Secara umum penelitian ini untuk mencari pengaruh model discovery learning berbantu software wingeom terhadap kemampuan pemahaman konsep matematis peserta didik. Sebelum dilaksanakan penelitian, peneliti menyusun beberapa instrumen berupa tes uraian sebanyak 8 nomor. Tes ini bertujuan untuk mengetahui kemampuan pemahaman konsep matematis peserta didik. Soal tersebut diuji cobakan di SMPN 12 Bekasi untuk mengetahui validitas, reliabilitas, tingkat kesukaran, dan daya beda soal. Dari hasil tesebut diperoleh bahwa semua soal valid, dan hasil koefisien reliabilitassoal sebesar 0,694 dengan kriteria reliabilitas tes tergolong tinggi yang sebelumnya diakukan perhitungan jumlah varians tiap butir soal sebesar 10,990 dan jumlah varians total sebesar 28,030. Hasil dari data tersebut dapat dilihat pada tabel 1. 
Tabel 1. Hasil Validitas, Tingkat Kesukaran, dan Daya Pembeda

\begin{tabular}{cccc}
\hline Nomor Soal & Validitas & Tingkat kesukaran & Daya pembeda \\
\hline 1 & 0,306 & 0,700 & 0,180 \\
\hline 2 & 0,570 & 0,930 & 0,090 \\
\hline 3 & 0,472 & 0,470 & 0,370 \\
\hline 4 & 0,647 & 0,710 & 0,360 \\
\hline 5 & 0,700 & 0,240 & 0,350 \\
\hline 6 & 0,780 & 0,480 & 0,650 \\
\hline 7 & 0,641 & 0,250 & 0,300 \\
\hline 8 & 0,421 & 0,256 & 0,250 \\
\hline
\end{tabular}

Jumlah populasi dalam penelitian ini adalah 80 orang yang melibatkan dua akelas dari SMP Desa Putera, yaitu kelas VIII sebagai kelas kontrol yang berjumlah 40 orang dan kelas VIII B sebagai kelas eksperimen yang berjumlah 40 orang. Dari jumlah populasi dan sampel tersebut, setelah melakukan penelitian dan mengerjakan instrumen berupa tes urain maka diperoleh data skor untuk mengetahui kemampuan pemahaman konsep matematis peserta didik. Adapun data skor peserta didik yang telah diolah dapat dilihat pada tabel 2.

Tabel 2. Hasil pengolahan skor peserta didik

\begin{tabular}{lcc}
\hline \multicolumn{1}{c}{ Keterangan } & Kelas kontrol & Kelas Eksperimen \\
\hline Rata-rata & 11,650 & 17,050 \\
\hline Normalitas & 0,120 & 0,120 \\
\hline Homogenitas & & 0,977 \\
\hline Uji perbedaan (Uji-t) & & 6,345 \\
\hline Effect Size & & 1,426 \\
\hline
\end{tabular}

Berdasarkan tabel diatas untuk hasil tes kelas eksperimen dan kelas kontrol menunjukkan bahwa rata-rata kemampuan pemahaman konsep matematis peserta didik kelas eksperimen yang diajarkan dengan menggunakan model discovery learning berbantu software wingeom lebih tinggi dibandingkan kemampuan pemahaman konsep matematis peserta didik di kelas kontrol yang tidak diajarkan dengan menggunakan model discovery learning berbantu software wingeom. Pada kelas kontrol skor terendah yaitu 5 dan skor tertinggi yaitu 22. Sementara pada kelas eksperimen skor terendah yaitu 10 dan skor tertinggi yaitu 26 .

Berdasarkan analisis perhitungan distribusi normal kelas kontrol pada taraf signifikansi 0,05 dan $n=40$ maka diperoleh hasil $L_{\text {hitung }}$ sebesar 0,120 dan $L_{\text {tabel }}$ sebesar 0,140. Karena $L_{\text {hitung }}=0,120<0,140=L_{\text {tabel }}$ maka dapat disimpulkan bahwa data berdistribusi normal. Begitupun juga dengan kelas eksperimen berdasarkan analisis perhitungan distribusi normal kelas eksperimen pada taraf signifikansi 0,05 dan $n=40$ maka diperoleh hasil $L_{\text {hitung }}$ sebesar 0,120 dan $L_{\text {tabel }}$ sebesar 0,140. Karena $L_{\text {hitung }}=0,120<0,140=L_{\text {tabel }}$ maka dapat disimpulkan bahwa data berdistribusi normal. 
Dari hasil perhitungan homogenitas diperoleh nilai $F_{\text {hitung }}=0,977$. Untuk $\alpha=0,05$ dengan $d k$ pembilang $=39$ dan $d k$ penyebut $=39$, dengan menggunakan metode interpolasi maka diperoleh $F_{\text {tabel }}=F_{0,05(39,39)}=1,715$. Jika dibandingkan, terlihat bahwa nilai $F_{\text {hitung }}$ kurang dari $F_{\text {tabel }}\left(F_{\text {hitung }}=0,977<1,715=F_{\text {tabel }}\right)$ maka $\mathrm{H}_{0}$ diterima, dengan demikian dapat disimpulkan bahwa varians kedua kelas bersifat homogen.

Berdasarkan hasil perhitungan rerata kelas eksperimen dengan kelas kontrol diperoleh $t_{\text {hitung }}$ $=6,345$ dengan taraf signifikansi 0,05 dan derajat kebebasan $(d k)$ sebesar 0,05 diperoleh $t_{\text {tabel }}=$ 1,667. Bila dibandingkan dapat dilihat nilai $t_{\text {hitung }}=6,345>1,667=t_{\text {tabel }}$, maka $H_{0}$ ditolak. Ditolaknya $H_{0}$ disimpulkan bahwa terdapat pengaruh model discovery learning berbantu software wingeom terhadap kemampuan pemahaman konsep matematis peserta didik.

Dari hasil pengujian hipotesis dengan uji- $t$ menghasilkan tolak $H_{0}$, yang berarti terdapat pengaruh model discovery learning berbantu software wingeom terhadap kemampuan pemahaman konsep matematis peserta didik. Untuk mengetahui seberapa besar pengaruhnya dapat dihitung menggunakan uji Effect Size. Dari hasil pengujian Effect Size diperoleh Effect Size (ES) sebesar 1,426, sehingga dapat simpulkan bahwa terdapat pengaruh model discovery learning berbantu software wingeom terhadap kemampuan pemahaman konsep matematis peserta didik.

Dari uraian hasil penelitian yang telah dipaparkan diatas, maka dapat disimpulkan bahwa model discovery learning berbantu media software wingeom diharapkan dapat memaksimalkan potensi peserta didik, khususnya pada kemampuan pemahaman konsep matematis. Sehingga model discovery learning berbantu software wingeom dapat menjadi salah satu alternatif pembelajaran yang dapat diterapkan oleh guru dalam proses pembelajaran.

\section{Simpulan dan Saran}

Berdasarkan hasil penelitian, maka dapat disimpulkan bahwa terdapat pengaruh model discovery learning berbantu software wingeom terhadap kemampuan pemahaman konsep matematis peserta didik. Analisis data skor kemampuan pemahaman konsep dengan menggunakan uji- $t$ diperoleh nilai $t_{\text {hitung }}=6,345>1,667=t_{\text {tabel }}$ dengan taraf signifikan $\propto=0,05$ maka dapat disimpulkan tolak $H_{o}$, karena nilai effect size yang didapat sebesar $1,426 \geq 0,8$ maka pengaruh positif tergolong tinggi.

Model discovery learning merupakan pembelajaran yang menekankan pada pengalaman langsung dan pentingnya pemahaman struktur atau ide-ide penting terhadap suatu disiplin ilmu, melalui keterlibatan siswa secara aktif dalam pembelajaran. Peserta didik yang terbiasa menemukan struktur dan ide-ide atau gagasan pengetahuan awal, maka kemampuan pemahaman 
konsep peserta didik akan terus berkembang. Software wingeom merupakan software matematika untuk membantu dalam topik geometri. Software wingeom membantu peserta didik dalam kemampuan pemahaman suatu konsep.

Kemampuan pemahaman konsep merupakan suatu kapasitas peserta didik dalam memahami konsep yang berhubungan dengan matematika. Model discovery learning ini dapat mengembangkan pemahaman konsep peserta didik dalam proses pembelajaran, dan juga peserta didik dapat berbagi informasi dan pegetahuan dari peserta didik lainnya dengan berbantu software wingeom.

\section{Referensi}

Ali Gunay, Balim. 2009. The Effects of Discovery Learning on Students' Succes and Inquiry Learning Skills. Eurasian Journal of Educational Research, Issue 35, hlm. 2

Sani, Ridwan Abduh. 2014. Pembelajaran Saintifik Untuk Implementasi Kurikulum 2013. Jakarta: PT Bumi Aksara.

Sutirman. 2013. Media dan Model-Model Pembelajaran Inovatif. Yogyakarta: Graha Ilmu.

Tianingrum, Risna dan Hanifah Nurus Sopiany. 2017. Analisis Kemampuan Matematis Siswa SMP Pada Materi Bangun Ruang Sisi Datar. Prosiding Seminar Nasional Matematika dan Pendidikan Matematika (SESIOMADIKA).

Trung Tran, Ngoc-Giang Nguyen,dkk. 2014. Discovery Learning with the Help of the GeoGebra Dynamic Geometry Software. Vietnam. Teaching and Education Research. Vol 7, hlm. 45

Zulkarnain, Iskandar. 2014. Model Penemuan Terbimbing Dengan Teknik Mind Mapping Untuk Meningkatkan Kemampuan Pemahaman Konsep Matematis Siswa SMP. EDU-MAT Jurnal Pendidikan Matematika. Vol. 2. 